A. R. Biggs

West Virginia University, Kearneysville

G. G. Grove

Washington State University, Wenatchee

\title{
Role of the World Wide Web in Extension Plant Pathology: Case Studies in Tree Fruits and Grapes
}

What is the Internet? In simplest terms,
the Internet can be thought of as a global network of computer networks. Information on the Internet is shared in many forms, including text, graphics, pictures, sound, and video. The portion of the Internet that allows for transfer and viewing of multimedia information is known as the World Wide Web. The web enables computer users to view and interact with a variety of information sources. Web resources are organized to facilitate easy movement from one web site to another. Users typically navigate, browse, or "surf" the World Wide Web using web brower or web client software (Netscape Navigator or Microsoft Internet Explorer, for example). The links on the web partially comprise the global Internet and form a massive multimedia knowledge base. A web site is a "place" created to allow others a reference point to a specific topic, organization, or individual, and to facilitate the transfer of information in which the site may specialize. The content of web sites is diverse, ranging from broad to very specific areas of interest. For a more detailed account on the technical definition of the Internet and its evolution, see http://physics.gac.edu/ departme/Internet.htm.

With the Internet influencing the stock market, shaping worldwide technical innovation, and appearing daily in the traditional print media, much discussion is occurring regarding the implications of the Internet for society, government, commerce, education, and other institutions. How has the Internet changed the way we live, work, learn, profit, govern, and communicate? Although it is beyond the scope of this article to address all of these issues,

Dr. Biggs' address is: West Virginia University, University Experiment Farm, P. O. Box 609, Kearneysville 25430.

This is manuscript No. 2638 of the West Virginia Agricultural and Forestry Experiment Station.

Publication no. D-1998-0302-01F

(C) 1998 The American Phytopathological Society our objectives are to: (i) convey our experiences with information sharing in plant pathology extension via the World Wide Web; (ii) provide background on hardware, software, site planning, and the time commitment needed to construct and maintain an active web site; (iii) address various institutional issues that arose during our endeavors; and (iv) provide a measure of current and future web-based technologies that potentially influence extension plant pathology.

\section{West Virginia University}

Experiment Farm, Kearneysville: http: //www.caf.wvu.edu/kearneysville/wvufar m1.html

The WVU-Kearneysville web site (Fig. 1) evolved from a mid-Atlantic regional effort to consolidate tree fruit monitoring information in book form (4). The original focus of the site was to provide online access to the plant pathology portion of the Mid-Atlantic Orchard Monitoring Guide in the form of color-illustrated "fact sheets"

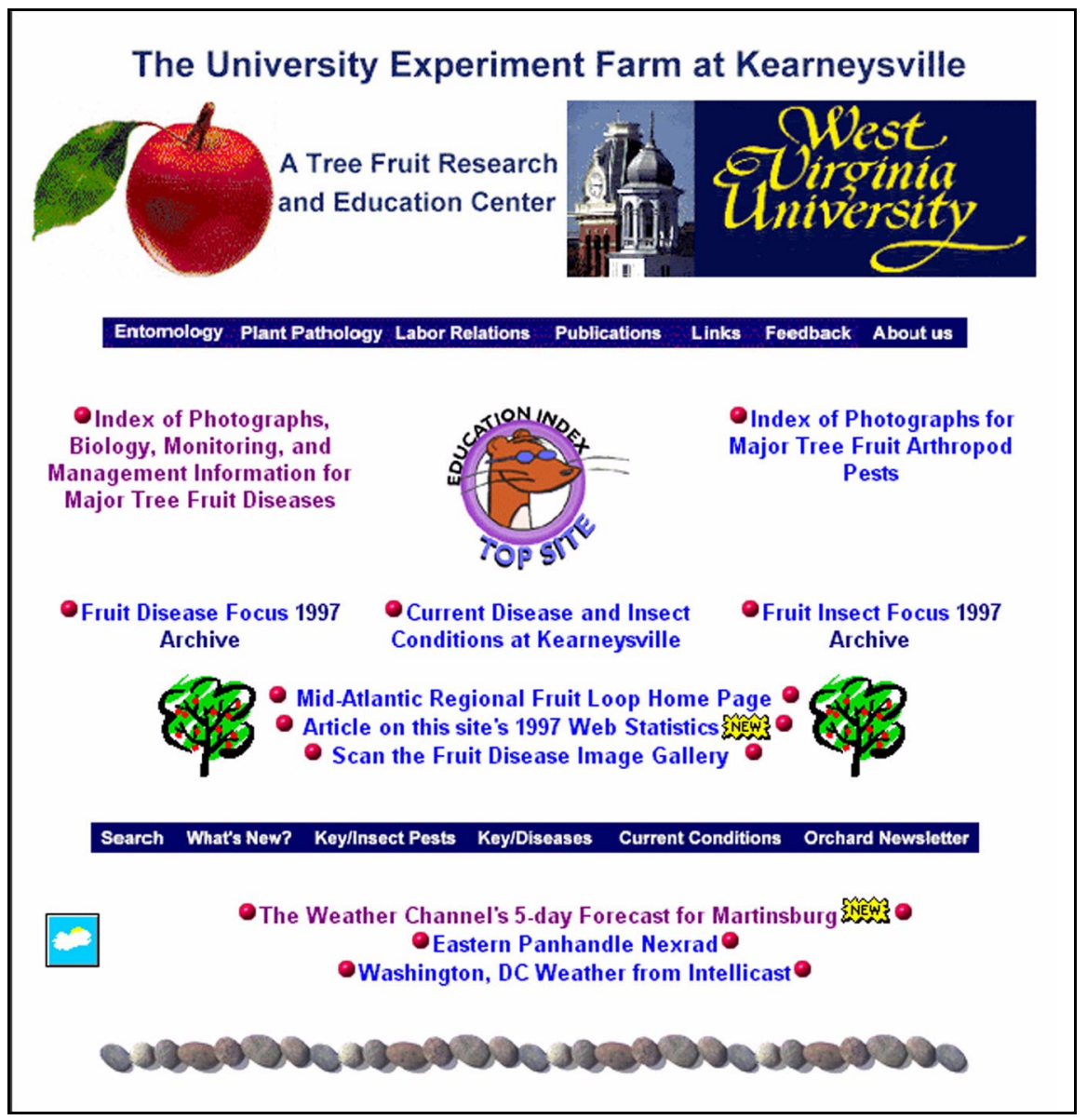

Fig. 1. Top portion of the West Virginia University Experiment Farm World Wide Web home page showing site banner graphic, counter, navigation bars, table of commonly used items, and links to weather information (http://www.caf.wvu.edu/kearneysville/wvufarm1.html). 
that could be printed and distributed as needed (Figs. 2 and 3). The secondary focus of the site was to provide a key for the identification of major tree fruit diseases. This portion of the content was based on the key developed by Schwarz and Burr (8), and modified by the senior author to include diseases of the mid-Atlantic region. The key and the fact sheet pages were designed to be linked, so that individual disease photographs could be used to illustrate and clarify symptom descriptions in the key, and the final diagnosis from the key process could be linked to the appropriate fact sheet and management recommendations.

Additional content provides site identification and information to familiarize users with the WVU Kearneysville Experiment Farm. The opportunity for web visitors to provide feedback also was included, and this feature was used as the basis for making improvements in design and content following the publication of the original material in November 1996.

The target audience for the Disease Key and Fact Sheets was county extension agents. All county extension offices in West Virginia were accessing the web by modem with Netscape 2.0 when the site was designed. The secondary audience included commercial fruit producers in the mid-Atlantic region, other fruit industry support representatives (including consultants), master gardeners, and the general public.

The WVU-Kearneysville web site evolved over the first 6 months after publication to include increased content and improved appearance. The evolution of the web content was based on the availability of additional phytopathology content (i.e., contribution of text and photographic material from Diseases of Tree Fruits in the East, by A. L. Jones and T. B. Sutton [5]), the use of a searchable html database of tree fruit pathology titles from APS journals (Plant Disease Reporter, Plant Disease, and Phytopathology), additional content provided by the WVU fruit entomologist, and the use of more-detailed descriptions of diseases and insect pests (revised monthly as features) than were provided in the fact sheets. In addition, tables comparing cultivar susceptibilities to various diseases have been prepared in cooperation with K. S. Yoder, fruit pathologist at Virginia Tech's Alson $\mathrm{H}$. Smith, Jr., Agricultural Research and Extension Center, Winchester, Virginia. The site currently consists of more than 190 pages and more than 300 photographs of fruit-related material in the disciplines of plant pathology, entomology, and agricultural labor relations.

In November 1996, we surveyed West Virginia fruit producers to determine the extent to which each of our extension programs was being utilized. The results of the survey showed that one of our more traditional extension strategies (radio broadcasts three times per week on three AM stations) for sharing information on current insect and disease conditions was not being used by a significant number of producers. This finding provided the impetus for testing the potential of providing current insect and disease conditions on the web. The Current Conditions web page (Fig. 4) was provided as a supplement to our Orchard Monitor newsletter and was to serve as an information bridge between the 2-week intervals covered by the newsletter and our monthly twilight meetings. During the apple bloom period, the current and predicted status of fire blight, as determined by the Maryblyt model, was posted on the Current Conditions page (11). Daily graphical images of the Maryblyt screen, along with an interpretation of the data, were made available (Fig. 4). Questions about Maryblyt and related items from the Feedback utility led to the creation of a Maryblyt FAQ (frequently asked questions) page, in cooperation with P. W. Steiner at the University of Maryland.

The evolution of the improved visual appearance was based on user feedback (i.e., a "What's New" page, so that repeat visitors could identify easily any new content). Additional site refinements were based on innovations in web server and client software capabilities (including use of graphical [rather than text-based] navigation aids, common gateway interface [CGI] scripts, ActiveX technology, animations, slide presentations, and Java applications).

Quality guidelines for content were established early in the process of site construction. Of particular importance were: (i) generally avoiding the publication of nonrefereed research materials; (ii) providing appropriate credit to original authors for text and photographs from the Mid-Atlantic Orchard Monitoring Guide, Diseases of Tree Fruits in the East, and other sources; and (iii) providing highresolution disease images that will download quickly by modem.

Data acquisition, use patterns, user feedback. The WVU-Kearneysville web site was visited approximately 15,000 times (unique URLs) in its first year online. Intensity of use of individual pages varies with time of year, with the Current Conditions page receiving the most visits during the period from 1 April through 1 August. The Index of Disease Photographs, Biology, and Monitoring Information page is visited frequently all year, as is the Key to Major Fruit Diseases. Number of user

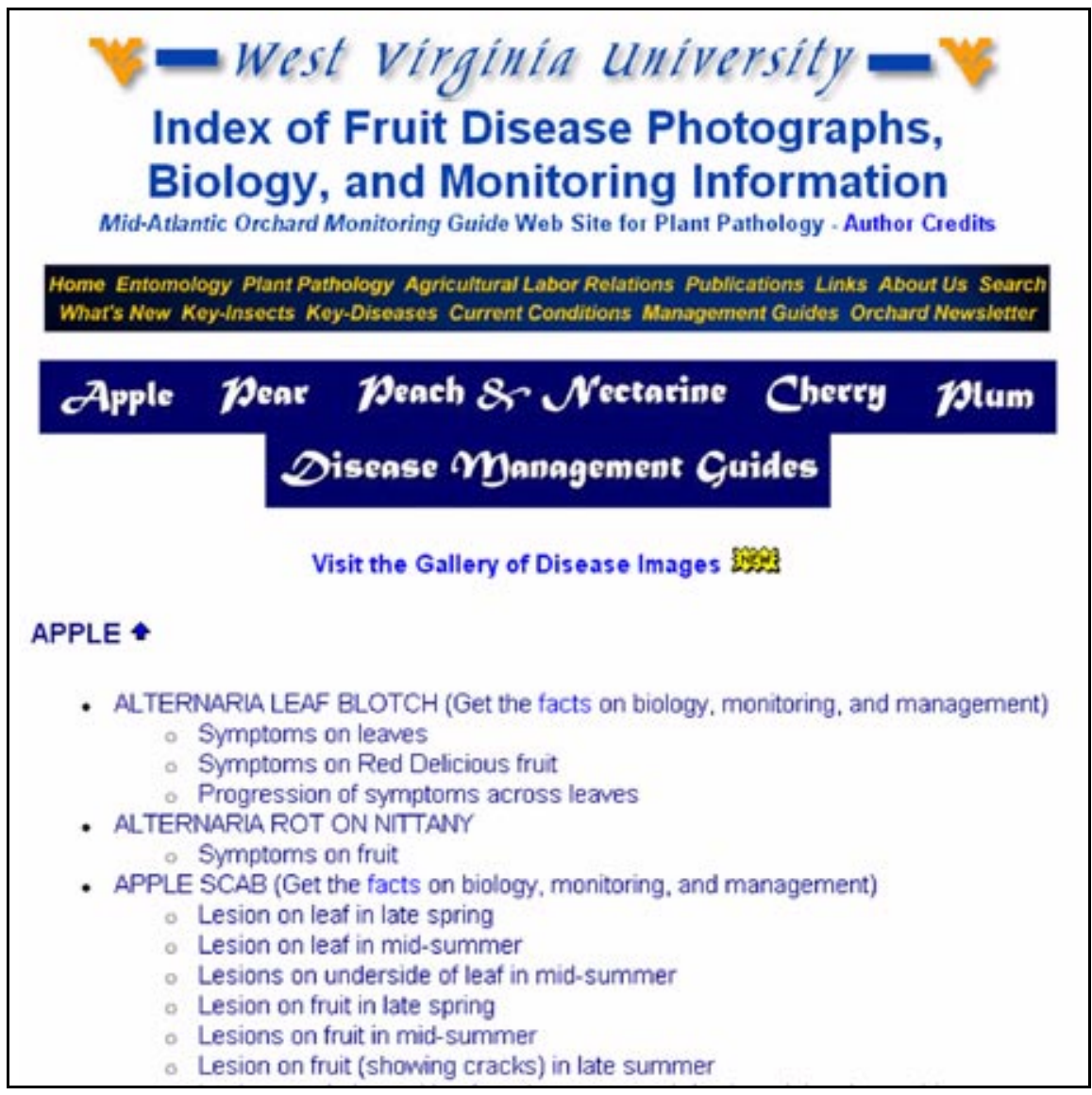

Fig. 2. Top portion of the Index of Fruit Disease Photographs, Biology, and Monitoring Information page from the West Virginia University Experiment Farm web site. Photographs and disease fact sheets that can be accessed from this page were compiled from the Mid-Atlantic Orchard Monitoring Guide and Diseases of Tree Fruits in the East (http://www.caf.wvu.edu/kearneysville/wvufarm8.html). 
sessions per month doubled between May 1997 and January 1998.

\section{Washington State University}

Tree Fruit Research and Extension Center: http://www.tfrec.wsu.edu

The Washington State University Tree Fruit Research and Extension Center (WSU-TFREC) web site evolved from a dial-up bulletin board system that was established primarily to provide area extension agents, growers, and field support personnel with e-mail capabilities, realtime weather data, and disease forecasting information, as well as disease diagnosis, pesticide labels and related information, disease reference information, and spray recommendations $(2,13,14)$.

With one-third of a position ( $0.33 \mathrm{FTE})$ in extension plant pathology dedicated to preharvest diseases of tree fruit and grapes in Washington, the specialist must strive for efficient time utilization, a goal often in conflict with telephone technology. Electronic mail appeared to provide a partial solution to the problem. We postulated that communication via e-mail was less apt to result in the caller questioning the specialist about peripheral issues once the main concerns were addressed. The inherent advantages of electronic information trans- fer for the processing and distribution of extension information also influenced our decision to further develop this form of extension programming and delivery.

History. The bulletin board was established to provide easier access to the Washington Public Agricultural Weather System (PAWS), a series of 50 remote weather stations linked to a central base station located at the Irrigated Agricultural Research and Extension Center (IAREC) in Prosser (6). PAWS was established in the agricultural areas of eastern Washington in 1987 and provided dial-up (using a computer and modem) access to raw weather data. However, use of the system was limited by the DOS-character-driven interface that a large portion of computer newcomers found cumbersome and intimidating. In 1992, a graphical user interface (GUI) was established at WSU-TFREC, which made access to the system easier. By increasing ease of use, the conversion to a GUI stimulated many people associated with the Washington fruit industry to purchase new computers or upgrade and/or learn how to use the computers they already owned. Several WSU-sponsored computer-training seminars were held at key locations throughout the fruit-growing regions. The bulletin board user base grew to include more than 500 growers, field support personnel, extension specialists and agents, researchers, and media reporters. Beginning in 1994, the system's information was incorporated into the WSUTFREC web site (Fig. 5A) when the growth of the Internet gradually rendered the bulletin board system obsolete. The bulletin board system was phased out in January 1997, and its information was made available only over the web. Some of the data processing functions once available on the bulletin board were adopted by other WSU servers (the Washington State University Public Agricultural Weather System and the WSU Pesticide Information Center Online [PICOL]), which are in turn cross-linked to appropriate pages on various WSU-TFREC HTML pages. Distribution of the various functions among several servers made more bandwidth available for other uses on each server.

Another goal in establishing the web site was to expedite information transfer by providing a transition from total dependence on printed publications to the inclusion of electronic publications. For example, the Washington Spray Guide for Tree Fruits in Eastern Washington (EB0419) is revised during late summer-early fall, but due to the lengthy printing process it routinely fails to reach the industry until late winter-early spring. During some years, growers have actually had to begin their spray programs without the current control recommendations contained in this publication. Electronic publication in HTML and PDF formats provides a more timely means of disseminating this form of information. In addition, the Washington State University Extension Bulletin Series on diseases of tree fruits and grapes is extremely difficult to keep current due to rapidly changing pesticide laws, emerging fungicide resistance, and printing delays resulting from financial stresses and personnel shortages. Electronic publication of the fruit disease series appears to offer the ultimate and timely solution to these problems.

One of our current projects is the conversion of all tree fruit and grape disease extension bulletins to HTML and PDF formats. The PDF versions have a more professional appearance than HTML versions and can be downloaded and printed on the client's computer and printer, respectively. The author can embed uniform resource locators (URLs) in the PDF files and link to remote servers on the Internet. For example, the WSU-TFREC PDF file on cherry powdery mildew is initially downloaded from the WSU-TFREC web site and eventually resides on the client's hard disk. Portions of hypertext within that document are linked to cherry spray tables on the WSU-TFREC server; when the client clicks on this hypertext, the latest chemical control recommendations are accessed via the web from the WSUTFREC server and appear on the client's
Fig 3. Portion of an online fact sheet on sooty blotch and flyspeck disease that was accessed from the page shown in Figure 2 (http://www.caf.wvu.edu/kearneysville/ disease_descriptions/omsooty.html). 
screen for printing or saving. In the case of a last-minute change in recommendations for a particular fungicide, electronic publication cuts the time lag between specialist and client from hours, days, or months to minutes. Another benefit of electronic transfer is software distribution. New versions and upgrades can be posted on the web and downloaded in minutes.

Televar Northwest, a private-sector Internet service provider (ISP), established local dial-up nodes in 1994 to provide local telephone access to the Internet throughout the fruit-producing areas of eastern Washington and actively advertised the service to the fruit industries. When the Washington Fruit Frost Program was terminated by the National Weather Service, Televar helped to sponsor, advertise, and host a fruit frost program provided by a private meteorological organization. In addition to providing each new subscriber with free Netscape Navigator browser software, it advertised itself as an electronic road map to public- and private-sector Washington tree fruit information. This business decision attracted a multitude of new subscribers and helped (via customer support and training seminars) each user to get connected to the Internet. The latter function lightened WSU Cooperative Extension's workload considerably. The role of customer hardware support (which was a major cooperative extension customer service function with the old bulletin board system) shifted to the private sector, allowing extension specialists to spend more time on subject and program issues.

Disease reference and control recommendations. The WSU-Fruit Pathology pages contain information on symptoms, epidemiology, control, and online references for the major diseases of tree fruits and grapes in eastern Washington. Each disease is treated as a separate HTML file, and photographic information is embedded into tables associated with each file. Fungicide recommendations (Fig. 6) are contained in separate HTML files, but hyperlinks exist between the reference and chemical control files. Fungicide information of an urgent or newsworthy nature is posted on the WSU-Pathology pages. For example, when a Section 18 registration was granted in April 1997 permitting the use of oxytetracycline for control of fire blight on apples, the information was available on the Internet within minutes of the granting of the permit. Citations to online references on both the WSU-
TFREC and WVU servers are linked to remote servers. For example, the WSUTFREC web site lists many materials posted in HTML format on the WVU web site; when the user selects the citation on the WSU-TFREC site, it connects to and displays the reference from the WVU site.

Audience and usage patterns. Our audience consists of corporate and private field consultants, growers, news media agents, county extension agents, researchers, extension specialists, students of fruit pathology at Wenatchee Valley College, and commercial and home fruit producers throughout the world. The WSU-TFREC site received about 63,947 requests for information from 1 June 1995 through 1 June 1997. The majority of these requests were for plant disease information $(22,567)$, followed by about 4,890, 9,502, $13,115,13,873$, and 1,000 requests for IPM information, program descriptions, weather information, horticultural information, and entomological information, respectively. The WSU-TFREC site has been visited by persons in 58 countries and all continents except Antarctica. Usage is highest during the spring and has increased significantly over a 2-year period.

\section{$\mathrm{V}=$ West virginia University $=\mathrm{V}$ \\ Current Insect and Disease Conditions at Kearneysville}

\section{April 8, 1997}

Fire blight: Here are graphics from Intellicast Weather and the Maryblyt program. The temperature data are current through Monday moming. April 7, 1997 (in the red section of the graphic). Predicted weather conditions are shown for today and the next three days (blue section). As you can see from the columns labeled B (blossoms open), $H$ (degree hours for epiphytic bacterial populations). W (wetting. rain or dew), and T (average daily temperature $60 \mathrm{~F}$ or above), and subsequently in $\mathrm{R}$ (risk), fire blight infection risk is high today, with infection periods forecast for Wednesday. Thursday, and Friday. Susceptible cultivars should be sprayed to protect against infection the day before or the day of infection. Sprays applied after infection will not provide complete control, although some variable degree of control will be achieved. See our Maryblyt FAQ for more info. Note the BBS (blossom blight symptoms) column in the graphic. When BBS reaches 100 , the first symptoms of fire blight (bacterial ooze at the base of the infected blossoms) should be observable in the orchard. See the Fire Blight "fact sheet" for photos.
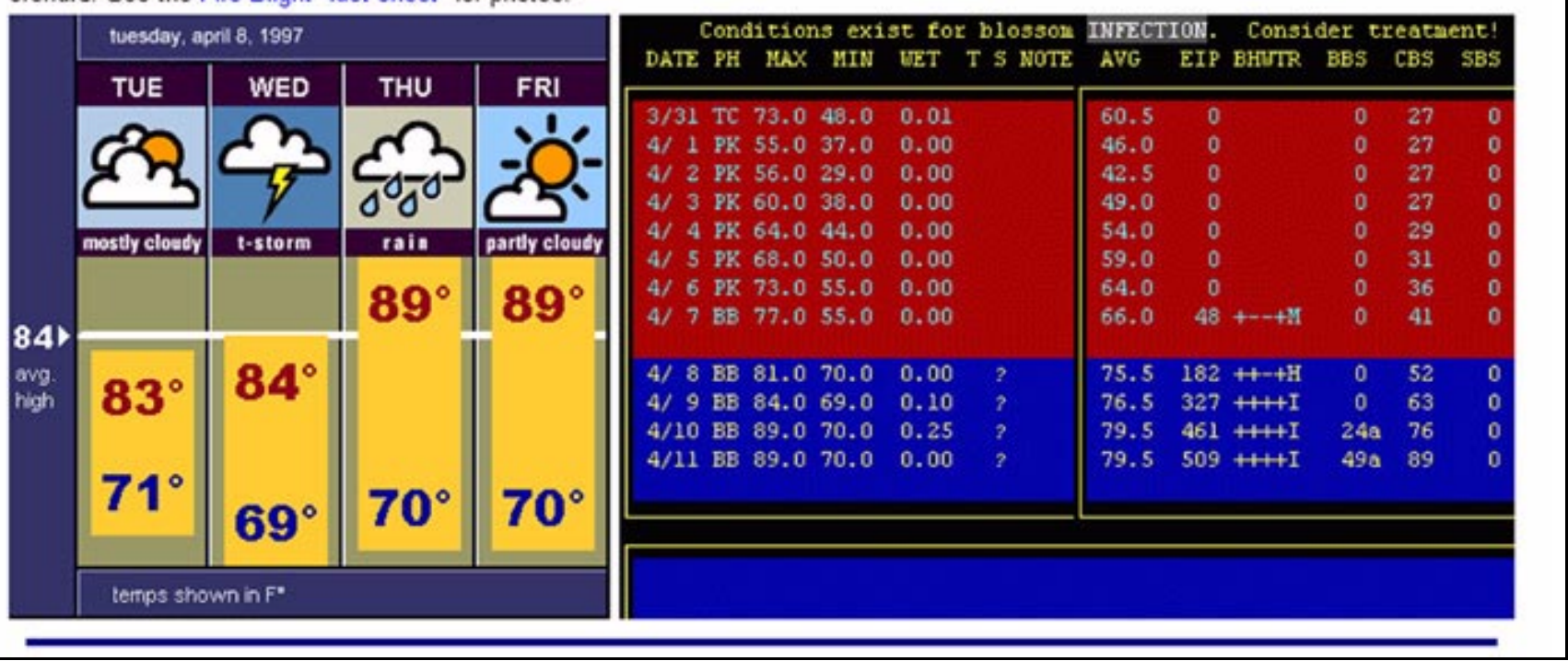

Fig. 4. Current Disease and Insect Conditions page from the West Virginia University Experiment Farm web site showing graphical weather forecast image and a Maryblyt forecast utilizing the forecasted weather data (http://www.caf.wvu.edu/kearneysville/current.html). 


\section{Institutional Support}

By providing support for salaries, computers, and software, both WVU and WSU extension administrations have been supportive of efforts on the web. However, the WSU-TFREC Internet projects would never have been possible without additional support from grant money or donations from the private sector. Additional grant support has not occurred for the WVU site. At both institutions, centralized departments involved in the creation and distribution of printed material have been unsupportive of decentralized Internet activities for several reasons. Some of the issues that need to be resolved include the location, maintenance, and "ownership" of the web site, responsibility for site maintenance, previous commitments to printed versus electronic publications, reluctance to change, financial destination of money collected through user fees, and issues relating to intellectual property and copyright infringement. Many of these issues remain unresolved at Washington State University and West Virginia University. The problems have arisen, in part, from the decentralization that makes the web so efficient for information transfer.

\section{Other Tree Fruit and Vine Sites}

Several web sites for general plant pathology and specific fruit-related information are available on the Internet (Table 1 and Fig. 7). In addition, there are excellent reference materials on viticulture, enology, and pomology available on the Internet (Fig. 7). Yahoo Internet searches utilizing wine grapes, wine, grapes, and grape diseases resulted in 57, 2,550, 116, and 78,280 site matches, respectively. One of the best wine- and vine-related sites on the Internet is the UC Davis Department of Enology and Viticulture (http://wineserver. ucdavis.edu/ven1.html). This site contains the most comprehensive list of links available. It provides easy access to many aspects of viticulture and enology in California and throughout the world. Excellent phytopathological information is available from numerous sources (Table 1). Sources most frequently used by the authors are the University of California Integrated Pest Management Project (Fig. 7A; http://www. ipm.ucdavis.edu/), the Pacific Northwest Plant Disease Control Handbook (Figs. 7C and 8; http://www.orst.edu/dept/botany/ epp/guide/index.html), the Northwest Grape and Berry Infonet (Fig. 7B; http://www.

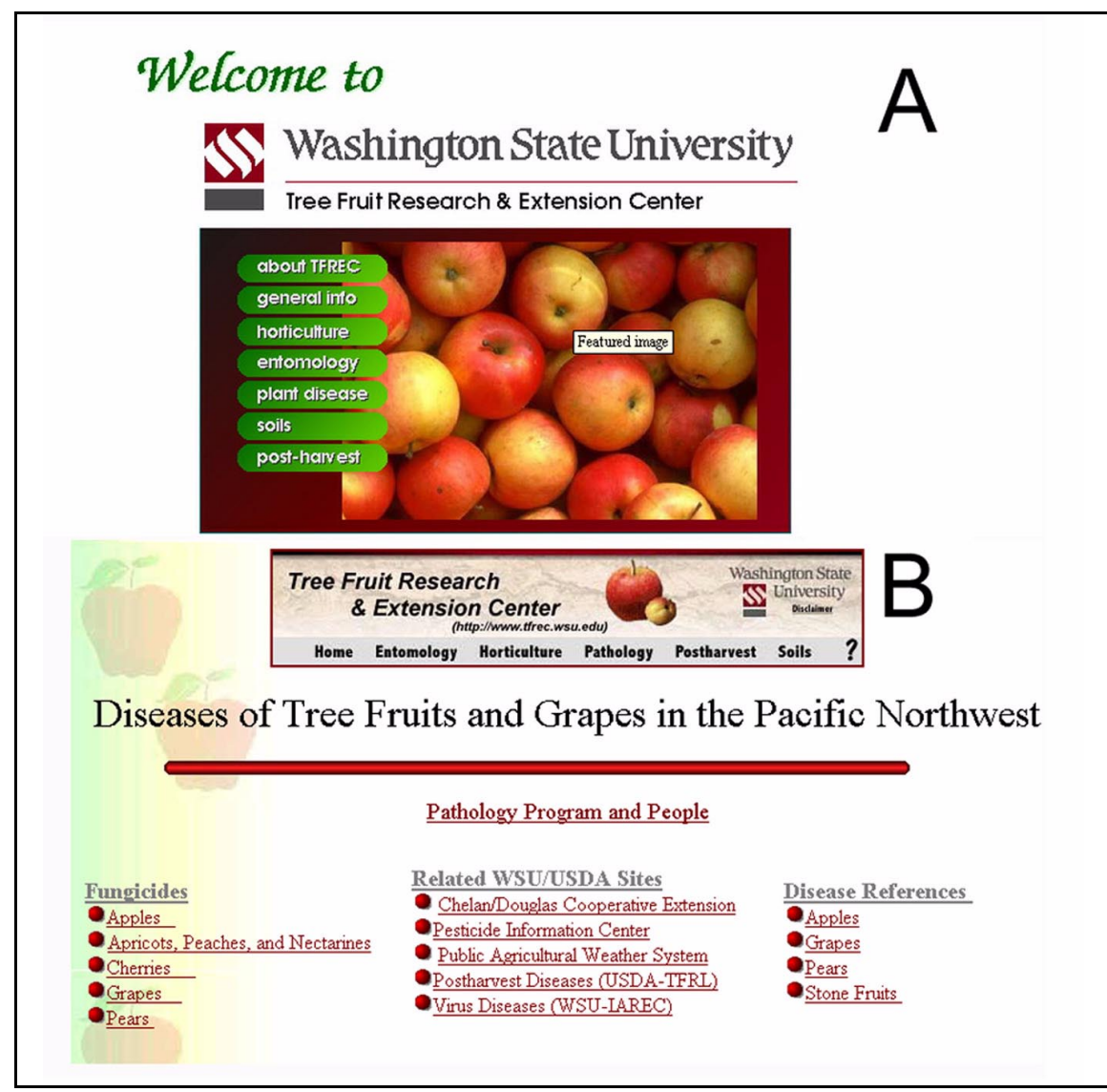

Fig. 5. Composite photograph of portions of (A) Washington State University Tree Fruit and Extension Center web site (http://www.tfrec.wsu.edu/) and (B) WSU-TFREC Fruit Pathology web site (http://www.tfrec.wsu.edu/Diseases/Main/Publish/main.htm). Portion A shows banner graphic, photograph, and buttons linking to WSU-TFREC Internet Resources made available by various disciplines at the institute. Portion B is a portion of the fruit pathology home page showing hypertext linkages to the various subject areas within the pathology web site.

orst.edu/dept/infonet/), the Ohio State University Fact Sheet Series for Fruit (http://www.ag.ohio-state.edu/ ohioline/lines/ fcrop.html), New York Integrated Pest Management (Fig. 7D; http://www.nysaes. cornell.edu/ipmnet/ny_ne/), and Michigan State University IPM (http://www.msue.msu. edu/ipm/fruit.htm). Examples of two Michigan State University web sites are provided (Figs. 9 and 10). The Van Buren County Extension Horticulture web site (Fig. 9) provided weekly updates of disease conditions in 1997, including a fire blight epidemic. At the Clarksville Horticultural Experiment Station, extensive data on the occurrence and prediction of apple scab are updated continuously (Fig. 10). All the sites mentioned provide excellent reference information on current spray recommendations, symptoms, pathogen biology, epidemiology, and control of troublesome grape and tree fruit diseases in their respective geographical areas. Information on tree fruit and grape diseases also can be obtained from other sites (Table 1).

\section{Status of the Technology: Washington State University}

Because of the excellent sources of diagnostic, epidemiological, and control information for tree fruits and vines on the web, people have at their fingertips a virtual library of reference information to aid in the identification, understanding, and control of plant diseases. How else might this Internet technology be applied in the orchard, warehouse, vineyard, or winery? In addition to the aforementioned uses, the web is being used to provide real-time data and other decision-making aids. Since 1986, there has been a gradual change from calendar- to weather-driven pesticide applications in Washington State. The change was initially brought about by the establishment of PAWS (Fig. 11; http://frost. prosser.wsu.edu), a system of weather stations (Fig. 11) positioned in key sites in the irrigated agricultural regions of eastern Washington. The system is headquartered at WSU-IAREC, with satellite receiving stations located in Wenatchee and Mount Vernon. The four weather stations in the Wenatchee Valley and WSU-TFREC base station were established by the second author in order to support long-term disease forecasting studies on fire blight of pear and the powdery mildews of apple, cherry, and peach. The PAWS system supports all agricultural commodities in eastern Washington. The weather stations consist of temperature, relative humidity, leaf wetness, soil moisture, soil temperature, solar radiation, and wind speed and direction sensors connected to CR-10 Dataloggers (Campbell Scientific, Logan, UT). Data are sent via radiotelemetry to receiving stations at WSU-IAREC, WSUTFREC, or WSU-Mount Vernon. The raw 
data are compiled at WSU-IAREC, and weather data and derived information are accessible through various WSU web pages. The PAWS user interface is interactive: clients select the weather data and models for a specific time period. Disease models currently on the system include apple scab (7), fire blight $(9,10)$ of apple and pear, and cherry (1) and grape powdery mildew models (12). A model for forecasting shothole of stone fruit (3) is scheduled for incorporation in early 1998. Other entomological, horticultural, and irrigation models also are available on the system.

Pesticide reference information, such as label information and toxicity, is provided by WSU's Pesticide Information Center Online (PICOL; http://picol.cahe.wsu.edu). The PICOL system, which is coordinated by entomologist Alan Schreiber, is an interactive retrieval system that contains online periodicals (e.g., Agrichemical and Environmental News), label and tolerance databases, and a pesticide notification network. Label information can be retrieved according to ingredient concentration, groundwater hazards, manufacturer, trade name, common name, pest, and type. Therefore, an end-user could conceivably use the web to diagnose, understand, and control a tree fruit disease from information provided on or linked to the WSU-
TFREC or WVU-Fruit Pathology pages. Our current challenge is to familiarize our clientele with this new technology.

\section{The Future of Web-Based Technology}

The potential of web-based technology in extension education is rooted in its ability to provide a learning environment in which the instructional materials are managed by the student (e.g., grower, consultant, etc.) rather than the educator (R. D. Weaver, personal communication). The keys to the potential learning power of web-based educational technology are

Table 1. Examples of World Wide Web sites offering phytopathological content in guidebook form and in the areas of tree fruits and vines

\begin{tabular}{lll}
\hline Content area & Site title & Uniform resource locator \\
\hline General & The Plant Pathology Internet Guidebook & http://www.ifgb.uni-hannover.de/extern/ppigb/ppigb.htm \\
& Agriculture Network Information Center (AgNIC) & http://www.agnic.org/ \\
& National Agriculture Library (USDA) & http://www.nalusda.gov/ \\
& National IPM Network & http://www.reeusda.gov/nipmn/
\end{tabular}

Fruit and vines

Fact sheets and handbooks

Journals

Periodicals

Organizations and institutes

Software/expert systems
Ohio State University Fact Sheet Series for Fruit

PNW Plant Disease Control Handbook

Washington State University Fruit Pathology

University of California IPM

New York Integrated Pest Management

Northwest Berry \& Grape Infonet

Michigan State University IPM

Michigan State University Van Buren County

Cooperative Extension

The Ohio State University Small Fruit Web Site

Midwest Small Fruit Pest Management Handbook

(The Ohio State University)

WSU Pesticide Information Center Online

University of California at Davis Department of

Viticulture and Enology

Virtual Orchard - Rutgers Cooperative Extension

and University of Vermont

West Virginia University Fruit Pathology

American Journal of Enology and Viticulture

Australian Journal of Grape and Wine Research

Journal of Small Fruit and Viticulture

UC Davis Viticulture and Enology Manuscript Archives

Journal of Sustainable Agriculture

Vineyard and Winery Management Magazine

CPM Magazine Online (Crop Net)

Good Fruit Grower Magazine

Australian Wine Online

California Agriculture

Great Lakes Fruit Grower Online

The Capital Press

Agrichemical and Environmental News

IPMNet News (Consortium for International Crop Protection)

Grape and Wine Research and Development

Corporation (Australia)

Geisenheim Research Station, Germany

Institut National de la Recherche Agronomique

CSU Winery / RPC / School of Wine \& Food Science

Activities and Other Related Information (Australia)

Cooperative Research Center for Viticulture (Australia)

Commonwealth Scientific Industrial Research

Organisation (CSIRO)

Royal Society of New Zealand

Vitis (Penn State)

Apple Orchard Consultant (Penn State) http://www.ag.ohio-state.edu/ ohioline/lines/fcrop.html http://www.orst.edu/dept/botany/epp/guide/index.html http://www.tfrec.wsu.edu/

http://www.ipm.ucdavis.edu/

http://www.nysaes.cornell.edu/ipmnet/ny_ne/

http://www.orst.edu/dept/infonet/

http://www.msue.msu.edu/ipm/fruit.htm

http://www.msue.msu.edu/vanburen/grapeweb.htm

http://www.msue.msu.edu/vanburen/disthort.htm

http://www.ag.ohio-state.edu/ sfgnet/

http://www.ag.ohio-state.edu/ ohioline/b861/index.html

http://picol.cahe.wsu.edu/

http://wineserver.ucdavis.edu/

http://orchard.uvm.edu/

http://www.caf.wvu.edu/kearneysville/wvufarm1.html

http://www.ajev.com/

http://www.winetitles.com.au/ajgwr.html

http://bubl.ac.uk/journals/agr/jsfav/

http://lib.ucdavis.edu/speccoll/html/viticul.html

http://bubl.ac.uk/journals/agr/jsusagr/

http://www.wines.com/vwm-online/

http://crop-net.com/

http://www.goodfruit.com/

http://www.winetitles.com.au/wineonline.html

http://danr.ucop.edu/calag/

http://orchard.uvm.edu/glfgn/default.html

http://www.capitalpress.com/

http://www.tricity.wsu.edu/ ebechtel/nwsltr.htm

http://ipmwww.ncsu.edu/cicp/IPMnet_NEWS/archives.html

http://www.winetitles.com.au/gwrdc.html

http://www.mnd.fh-wiesbaden.de/

http://www.inra.fr/

http://www.csu.edu.au/research/rpcgwr/winery.htm

http://www.csu.edu.au/research/rpcgwr/crcv.htm http://www.pi.csiro.au/

http://www.rsnz.govt.nz/publ/index.html

http://server.age.psu.edu/esdg/VITIS.html

http://server.age.psu.edu/esdg/PSAOC.html 
improved access to instructional material and the multimedia nature of the web content. By substantially reducing access time and cost of materials, the web offers an environment in which users can rapidly get the information they need to make good management decisions, and can explore elementary and advanced learning materi- als in a leisurely manner. The web provides a learning environment that accounts for cognitive flexibility, or different ways of learning. Web-based educational technologies make differences in learning styles among clients less problematic by reducing the cost of access to educational material, thus allowing the participants to experi-

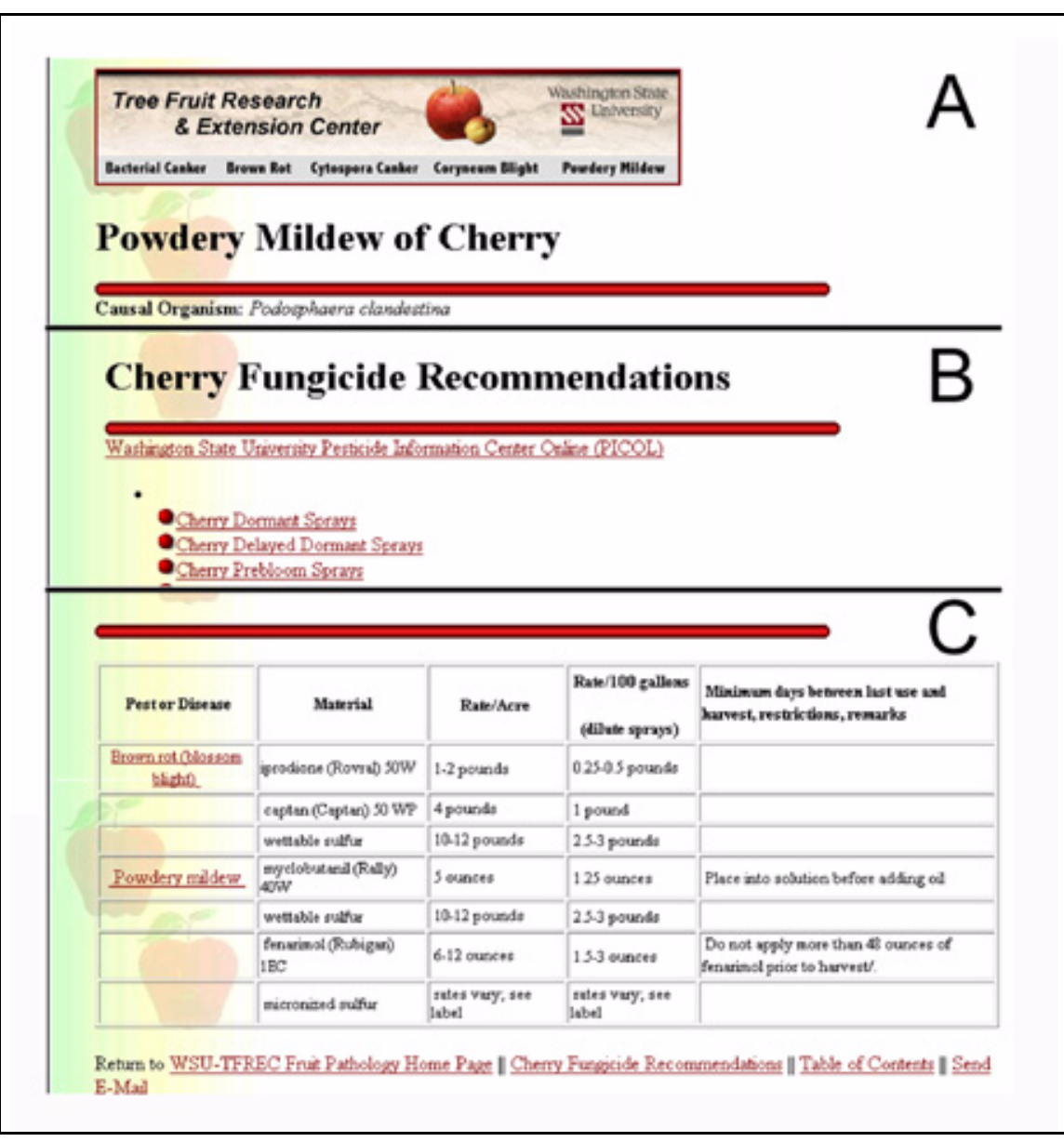

Fig. 6. Composite photograph of HTML files on powdery mildew of cherry (http://www.tfrec.wsu.edu/Diseases/Main/Publish/Stonedis/ma08017.htm). (A) Top portion reveals the title, (B) middle segment shows chemical control menu, and (C) represents chemical control recommendations for the disease. Hypertext in segment $C$ links back to the separate HTML page describing the disease $(A, B)$. ment with learning and find paths through materials that are most effective on an individual level.

Web-based instructional technology offers the potential to move away from more traditional methods of information delivery. Benefits of the technology include lower cost of instructional materials, enlarged scope of materials, and enhancement of many aspects of the learning process. For example, word searching allows high-speed identification and review of key concepts and definitions; Internet-based listservs or chatrooms allow participants to eliminate most costs of group interaction; and virtual tours through video or other media allow low-cost access to simulated environments in which participants apply concepts and skills. One of the potential difficulties of this instructional approach is the issue of academic credit for student hours. University administrators and state licensing and certification officials will need to develop accountability systems for Internet education activities to justify and ensure appropriate levels of funding and educational credit.

These new approaches to information acquisition make it feasible to begin investigating alternative approaches to design and delivery of extension programs. Through interactions on the web between extension personnel and agricultural producers, problems may be quickly elicited and assessed, allowing more effective time utilization. Another potential benefit of web-based delivery is that the users also may select their own educational objectives. This possibility implies that the population for which web-based material may be of interest is substantially broadened beyond the site designer's initial goals. With these issues in mind, procedures need to be developed to evaluate how well students are absorbing key material. Some procedures need to be developed for ensuring comparable levels of rigor in the educational process between classroom and Internet experiences.

Table 2. Current and future prospects for web-based plant pathology extension programs

\begin{tabular}{|c|c|c|c|}
\hline Potential technology & Current use & Potential use & Example uniform resource locator (if available) \\
\hline $\begin{array}{l}\text { Posting of traditional course materials } \\
\text { (syllabus, notes, glossary, data, schedules) }\end{array}$ & Low & High & $\begin{array}{l}\text { http://www.ento.vt.edu/Fruitfiles/VAFS.html (Tree Fruit IPM) } \\
\text { http://www.cas.psu.edu/docs/casdept/turf/turf235/turf235.html } \\
\text { (Turf Management [Turf 235]) }\end{array}$ \\
\hline Posting of examples & & & \\
\hline $\begin{array}{l}\text { Posting of downloadable data and analytical } \\
\text { function software }\end{array}$ & Low & Moderate & http://www.ento.psu.edu/home/extension/km/skw01.htm \\
\hline $\begin{array}{l}\text { Interactive access to web-based information } \\
\text { and data }\end{array}$ & Moderate & High & $\begin{array}{l}\text { http://www.tfrec.wsu.edu/ } \\
\text { http://www.caf.wvu.edu/kearneysville/wvufarm1.html }\end{array}$ \\
\hline Virtual tours & Low & High & http://res.agr.ca/lond/pmrc/tour/lond_tour.html \\
\hline Self-assessment & Not used & High & \\
\hline $\begin{array}{l}\text { Direct e-mail links, connectivity via listserv } \\
\text { or chatrooms }\end{array}$ & Low & High & $\begin{array}{l}\text { http://crop-net.com/ (go to Talk) } \\
\text { http://orchard.uvm.edu/forum/ }\end{array}$ \\
\hline Presentation of problem sets and cases & Low & High & http://orchard.uvm.edu/interaction\$/forum/DIAGNOSIS?id=4740563 \\
\hline $\begin{array}{l}\text { Presentation of instructional text, lecture } \\
\text { notes, slides, image galleries }\end{array}$ & Moderate & High & http://www.caf.wvu.edu/kearneysville/pathology.html \\
\hline
\end{tabular}


The current dominant use of the web in plant pathology extension education involves presentation of information that might otherwise be presented in hard copy (Table 2). With this approach, web technologies again offer reduction in access cost for the user (including increased convenience, improved time utilization, and the potential for reduced monetary investment) as well as reduced publication costs for the institution (although online availability of for-profit publications could be viewed as disadvantageous unless and until the general public develops confidence in the security of online financial transactions). It should be noted that these potential benefits of web-based extension instruction, although seemingly reasonable, have not been documented. Although current uses in university resident instruction include examples of most potential uses offered by web technologies (Table 2), their use in agricultural extension education is only emerging, and only a few examples are available. The perceived lag in the introduction of web-based technology between resident and extension education is most likely due to the lack of computer skills on the part of both extension faculty and agricultural client groups, as well as institutional impediments to rapid information delivery utilizing electronic media. A notable and possible future technology not included in Table 2 is artificial intelligence-directed learning and Internet-based expert systems.

Media-based technologies are, for the most part, limited to static presentations in standard HTML formats. Little use is made of currently available software enhancements such as Java applications, multimedia enhancements, Active Channel technology or "push" for information sharing, greater audio and video streaming capability (e.g., the Virtual Orchard site with Real Audio and Real Video capability [http://orchard.uvm.edu/nacaa/default.html ]), CD-ROM availability for extension fact base and information resource hyperlinks, built-in help (online expert system), more FAQs (answers to frequently asked questions), greater control and flexibility of page construction, and interactive pages. Further development of multimedia enhancements by software and hardware developers and their use by extension professionals are required if the power of the web is to be fully realized.

Web pages are changing the nature of plant pathology extension for educators. Growers with access to the web have a greater fact base from which to formulate questions and potential solutions that they bring to the extension professional. This requires that extension professionals be fully versed in what the web has to offer within their area of expertise. Obviously, the web will not totally replace the need to be in the field, although some reduction in this activity could be achieved with digital photography and electronic mail. Use of electronic mail will reduce time spent on the telephone for both producers and extension professionals. Some constraints of this technology as an extension tool in the near term include the technological capabilities of educators and users, commit- ment to keep information current on the part of educators, resistance of the university information bureaucracy to allowing educators online with unedited material (Information specialists often demand editing privileges on all extension materials, an impediment to the online publication of

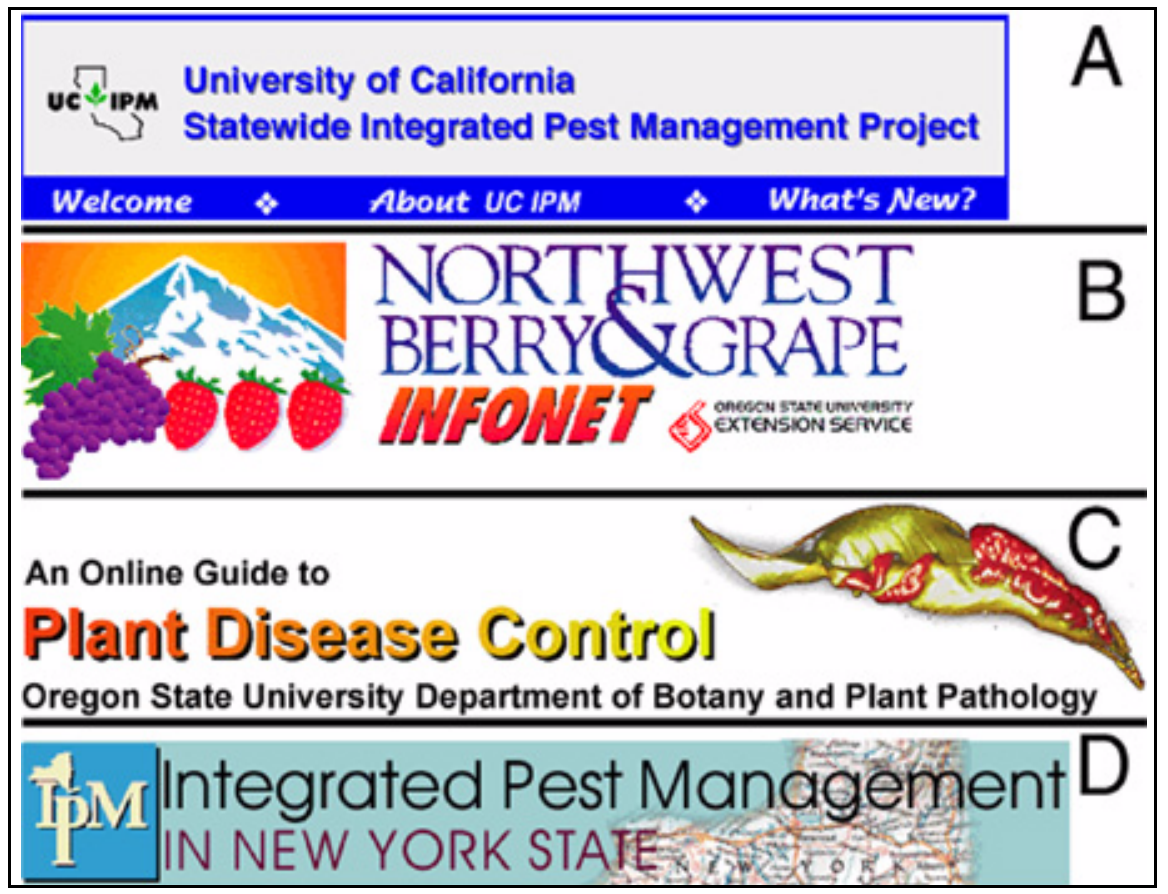

Fig. 7. Representative sites on the World Wide Web that contain phytopathological information on grapes. Title banners of $(A)$ the University of California Statewide Integrated Pest Management Project (http://www.ipm.ucdavis.edu/), (B) Northwest Berry \& Grape Infonet (http://www.orst.edu/dept/infonet/), (C) Oregon State University Department of Botany and Plant Pathology Online Disease Control Guide (http://www. orst.edu/dept/botany/epp/guide/index.html), and (D) Integrated Pest Management in New York State (http://www.nysaes.cornell.edu/ipmnet/ny_ne/).

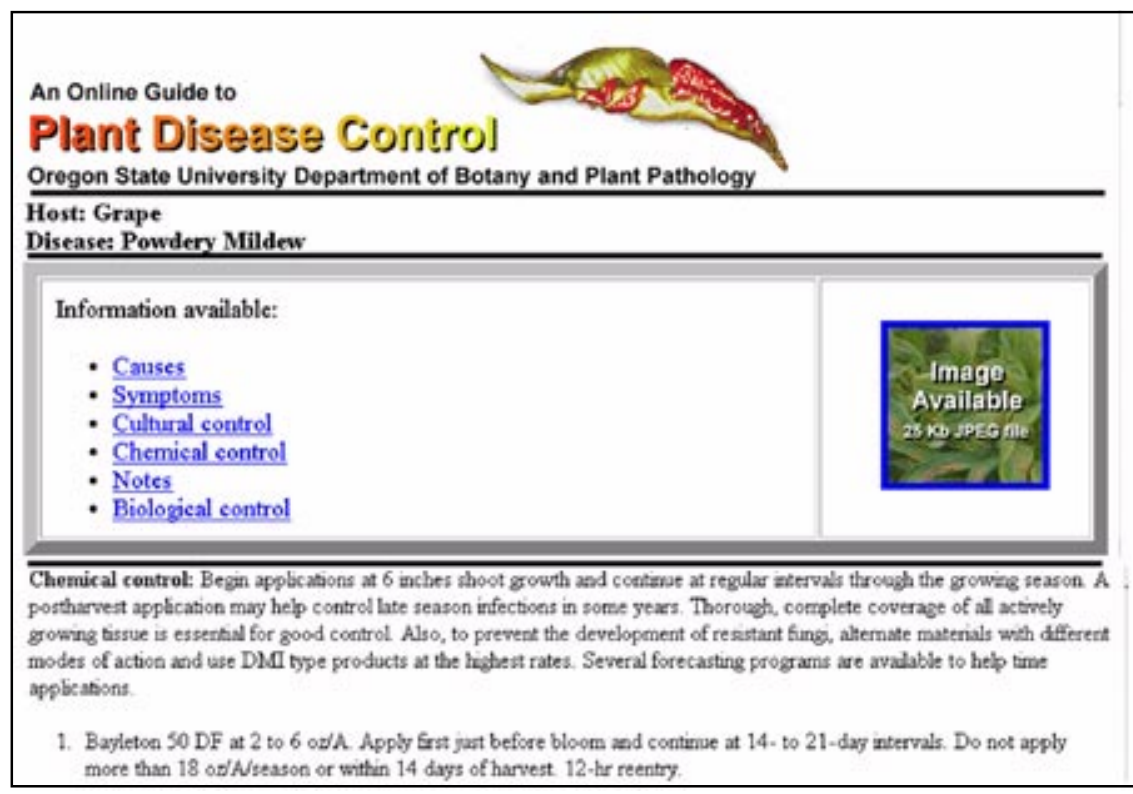

Fig. 8. Composite photograph of grape powdery mildew information served by the online version of the 1996 Plant Disease Control Handbook at Oregon State University (http://www.orst.edu/dept/botany/epp/guide/index.html). (A) Title banner, (B) host and disease, (C) mildew-related hypertext, and (D) sample control recommendation. 

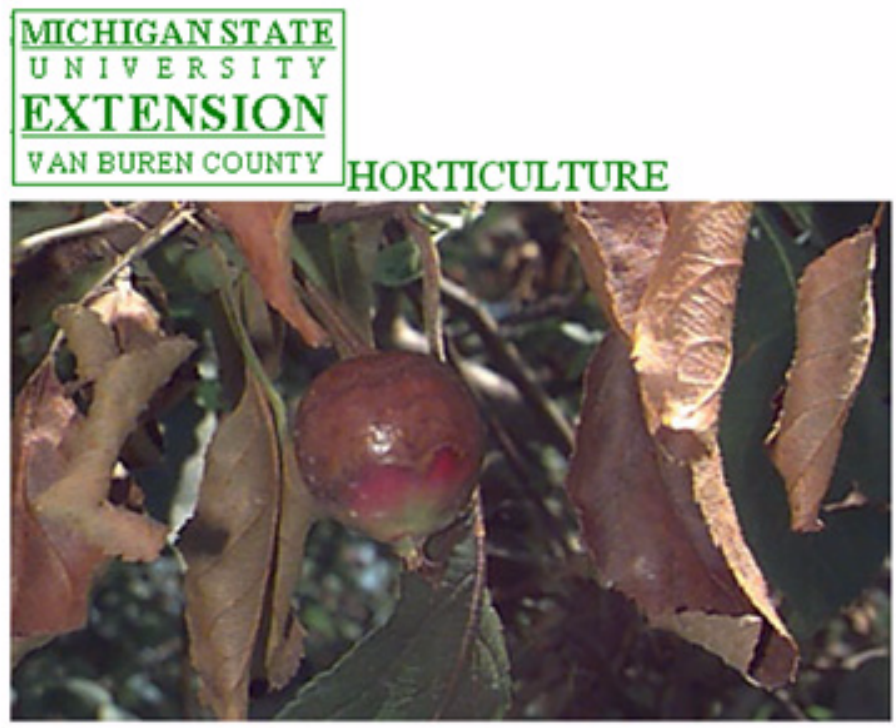

Fireblight is everywhere!

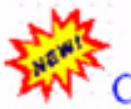

Current Crop Conditions, a review of current pest and disease conditions for fruit crops in Southwest Michigan. This regional report and disease updates is updated weekly.

\section{Current Weather conditions and Weather Web sites}

Fig 9. Fire blight update from July 1997 from the Van Buren County, Michigan, Cooperative Extension Office (http://www.msue.msu.edu/vanburen/disthort.htm).

time-sensitive material.), and university server security issues and the attendant limits on multiple user access.

Solutions to these potential problems include improved access and reduced costs of new hardware (Pentium PCs with $>150$ $\mathrm{MHz}$ processor speeds) and software (32bit operating systems), specialized training, dedicated servers or off-campus Internet service providers, and relaxed rules or decentralized information transfer systems for time-sensitive materials. An onsite peer review committee must approve any material posted on the WSU-TFREC web site.

\section{Web Professionalism}

The World Wide Web is diversifying our jobs as extension professionals by adding the role of providing information access to the traditional role of providing information. We find ourselves at times becoming less involved as information sources and more involved as information conduits. The web is the ideal tool for this endeavor and can make us more efficient if we utilize it correctly and professionally. The levels of professionalism that we respect in our printed media should also apply to electronic media. The Internet has been described by some as the "last frontier." In this regard, the medium offers us a great deal of freedom and potential for scholarly expression, but it also demands from us the observance of high ethical and professional standards. Our professional use of the Internet as a publications and information transfer medium demands strict adherence to the Code of Ethics of the American Phytopathological Society.

One aspect of the Internet that is relevant to extension is the virtual dissolution of state and national boundaries. When used appropriately, the web allows the extension specialist more freedom to devote time to other professional endeavors. For example, recently, numerous Washington users of the WSU-TFREC Fruit Pathology pages requested an online listing of rootstock and scion susceptibility to fire blight. In times past, this would have involved a literature review, writing time, publication arrangements, and distribution. Today, the solution was to provide links to this information, which was already available at the WVU web site. Identifying the author and location of the material was provided as a professional courtesy. Visitors to the WSU-TFREC site are given the name of the author of the requested material and told that they are leaving the WSU-TFREC site to get it. Electronic text, graphics, or tabular publications should be treated similarly to printed publications: World Wide Web sites, electronic publica- tions, images, and their authors should be credited and cited in a manner consistent with that of our printed publications.

\section{Establishing a Web Site}

Establishing a presence on the World Wide Web requires Internet access, a server for electronic distribution of the posted material, and web page or siteauthoring software. The task can be made easier if the prospective web author has access to document and slide scanners, imaging software (e.g., Adobe Photoshop or Ulead Photoimpact), and software capable of generating PDF documents (e.g., Adobe Acrobat).

Internet access. Most educational institutions and larger corporations provide Internet access and may provide potential web authors with space on their servers (see below). If you have such a connection, the next steps in establishing a web site are selecting a server and placing your material on it. Also, it is possible to establish a web site with an independent Internet service provider (ISP). Many ISPs offer space on their servers for the subscriber's web pages and offer assistance in getting the web site established. Most ISPs will be reluctant to host large (e.g., >5 MB) sites. If you already have Internet access, some private ISPs will host small web sites $(<2$ MB) free of charge (e.g., www.geocities. com).

Hardware and software requirements. WVU-Kearneysville web site files are located on a Unix server in the Agricultural Sciences Building in Morgantown. The WSU-TFREC web site is housed on a 66 $\mathrm{MHz} 486$ computer running the Windows NT operating system. Both servers are accessible via Ethernet or via remote FTP or Telnet, and files are uploaded to the site from the authors' desktop (office and home) personal computers, which use the Windows 95 operating system. Access to the servers requires a user name and password that were provided by the system administrators. Excellent site-hosting configurations are also available for the Macintosh. There are numerous site-hosting software packages available for every computing platform, although discussion of server software is beyond the scope of this article.

Design issues and considerations. The WVU-Kearneysville and WSU-TFREC web sites have been through major redesign efforts since their inceptions. The purpose of the redesigns was to improve the layout and navigability of the sites with newly available software. Other design issues that needed to be addressed were size of graphic images, screen fonts, use of sound and movement on the pages, and the general visual appeal of the sites. All these issues were examined in the context of our target populations, i.e., county agents, field consultants, and growers with $14.4 \mathrm{~kb} / \mathrm{s}$ 


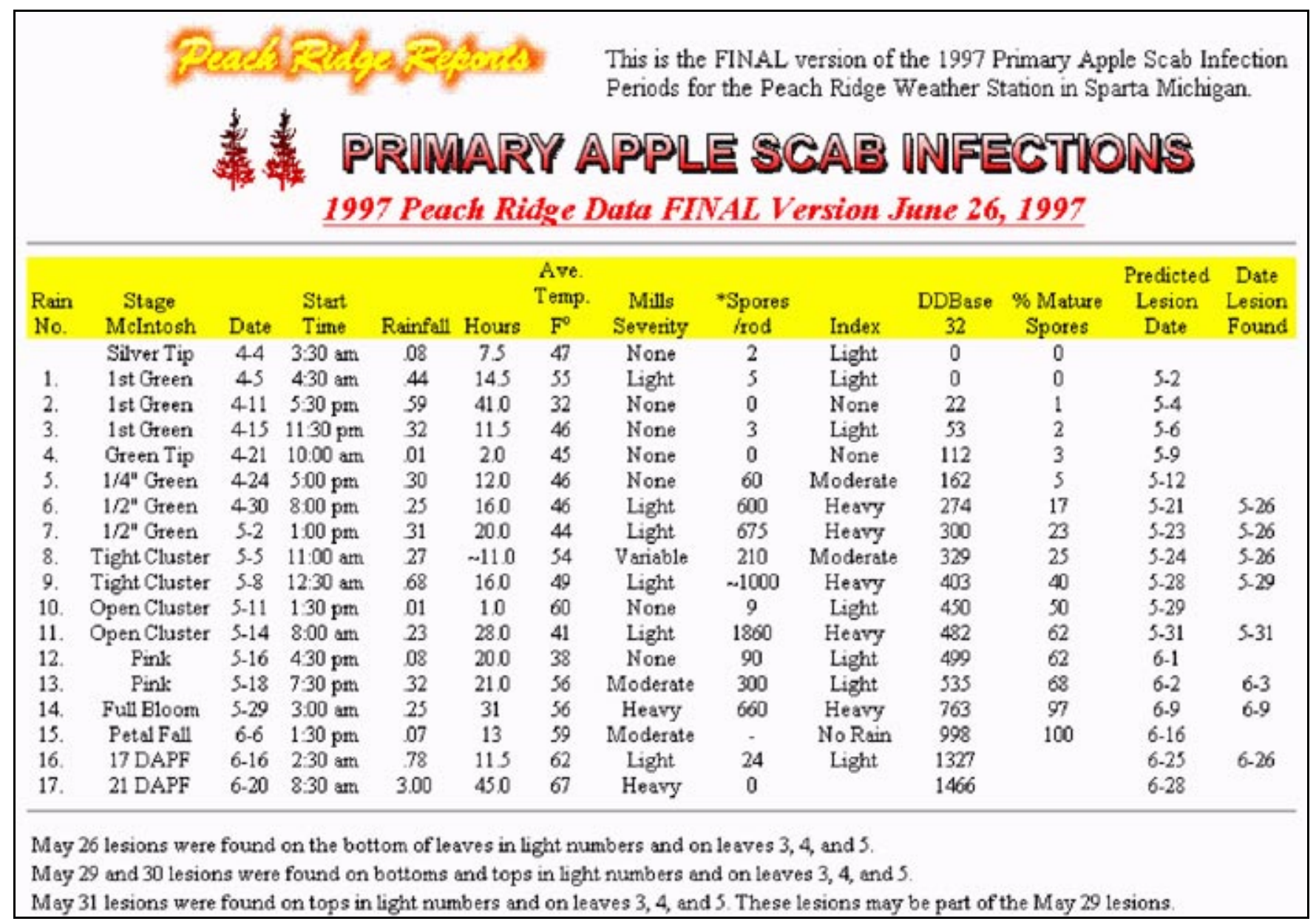

Fig. 10. Final 1997 apple scab report from the Peach Ridge Weather Station, from the Michigan State University Clarksville Horticultural Experiment World Wide Web site (http://www.canr.msu.edu/wchrs/).

modems. Some mistakes were made in which users with $640 \times 480$ pixel screen resolution had to scroll left and right to view the too-wide header graphic. On other pages, large images occasionally overlapped and covered text. Testing the pages prior to publication with both Netscape and Microsoft Internet Explorer at $640 \times 480$ screen resolution is now routine. Design for the least-sophisticated hardware is necessary in order to avoid losing a portion of the intended audience. A third design, currently in development, includes a "shared border" approach to the layout of the pages and employs dynamic html, data binding, and channel (or "push") technology. This version is based on the capabilities of Microsoft Internet Explorer 4.0 and is under construction with Microsoft FrontPage98. Although it is tempting at times to implement new technologies into web pages, the effectiveness of the site can be reduced if the computer capabilities of the intended audience are not considered. Extensive knowledge of HTML programming is not necessary to produce useful, informative, and attractive web pages. However, depending upon the capabilities of the software, some knowledge of the fundamentals of html is necessary. There are many resources on the web for tutorials, guides,

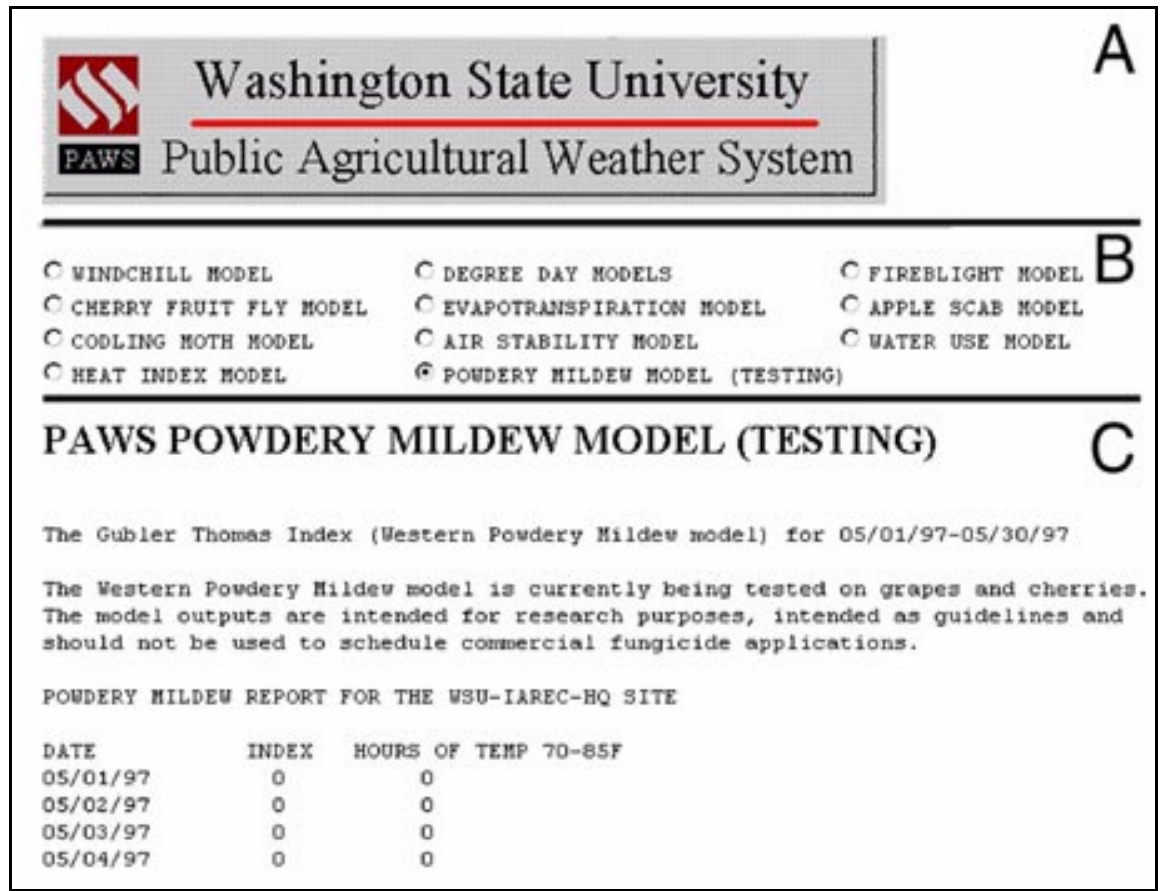

Fig. 11. Composite photograph containing various segments of various HTML files comprising disease forecasting information available on the Washington State University Public Agricultural Weather System (PAWS) (http://frost.prosser.wsu.edu/). (A) Title banner, (B) model choices, and (C) representative grape powdery mildew model printout. 
Table 3. World Wide Web sites for obtaining free software and tutorials for site authoring

\begin{tabular}{|c|c|c|}
\hline Content area & Site/software title & Uniform resource locator \\
\hline $\begin{array}{l}\text { Web browser/HTML editor } \\
\text { packages }\end{array}$ & $\begin{array}{l}\text { Microsoft Internet Explorer } 4.0 \\
\text { Netscape Communicator } 4.0\end{array}$ & $\begin{array}{l}\text { http://www.microsoft.com/ie/download/ } \\
\text { http://www.netscape.com/download/index.html }\end{array}$ \\
\hline HTML editor & Arachnophilia Home Page & http://www.arachnoid.com/arachnophilia/ \\
\hline Web page design & $\begin{array}{l}\text { HTML Writer's Guild } \\
\text { MediaBuilder } \\
\text { Web Pages That Suck }\end{array}$ & $\begin{array}{l}\text { http://www.hwg.org/ } \\
\text { http://www.mediabuilder.com/index1.html } \\
\text { http://www.webpagesthatsuck.com/ }\end{array}$ \\
\hline Web page authoring & Microsoft & http://www.microsoft.com/workshop/author/default.asp \\
\hline Images & $\begin{array}{l}\text { HTML Goodies, Joe Burns, Ph.D. } \\
\text { Microsoft } \\
\text { ARS Image Gallery }\end{array}$ & $\begin{array}{l}\text { http://www.htmlgoodies.com/ } \\
\text { http://www.microsoft.com/gallery/files/images/default.htm } \\
\text { http://www.ars.usda.gov/is/graphics/photos/ }\end{array}$ \\
\hline HTML reference & $\begin{array}{l}\text { HTML Writer's Guild } \\
\text { HTML Reference Library }\end{array}$ & $\begin{array}{l}\text { http://www.hwg.org/resources/useful.html } \\
\text { http://subnet.virtual-pc.com/ le387818/ }\end{array}$ \\
\hline Site building newsletter & Microsoft & http://www.microsoft.com/sitebuilder/ \\
\hline HTML tutorials & $\begin{array}{l}\text { Beginner's Guide to HTML } \\
\text { HTML Goodies, Joe Burns, Ph.D. }\end{array}$ & $\begin{array}{l}\text { http://www.ncsa.uiuc.edu/General/Internet/WWW/HTMLPrimer.html } \\
\text { http://www.htmlgoodies.com/ }\end{array}$ \\
\hline FTP software & WS_FTP Limited Edition & http://www.ipswitch.com/downloads/index.html \\
\hline General software sites & $\begin{array}{l}\text { TUCOWS } \\
\text { Stroud's }\end{array}$ & $\begin{array}{l}\text { http://tucows.phx.cox.com/ } \\
\text { http://cws.internet.com/index.html }\end{array}$ \\
\hline
\end{tabular}

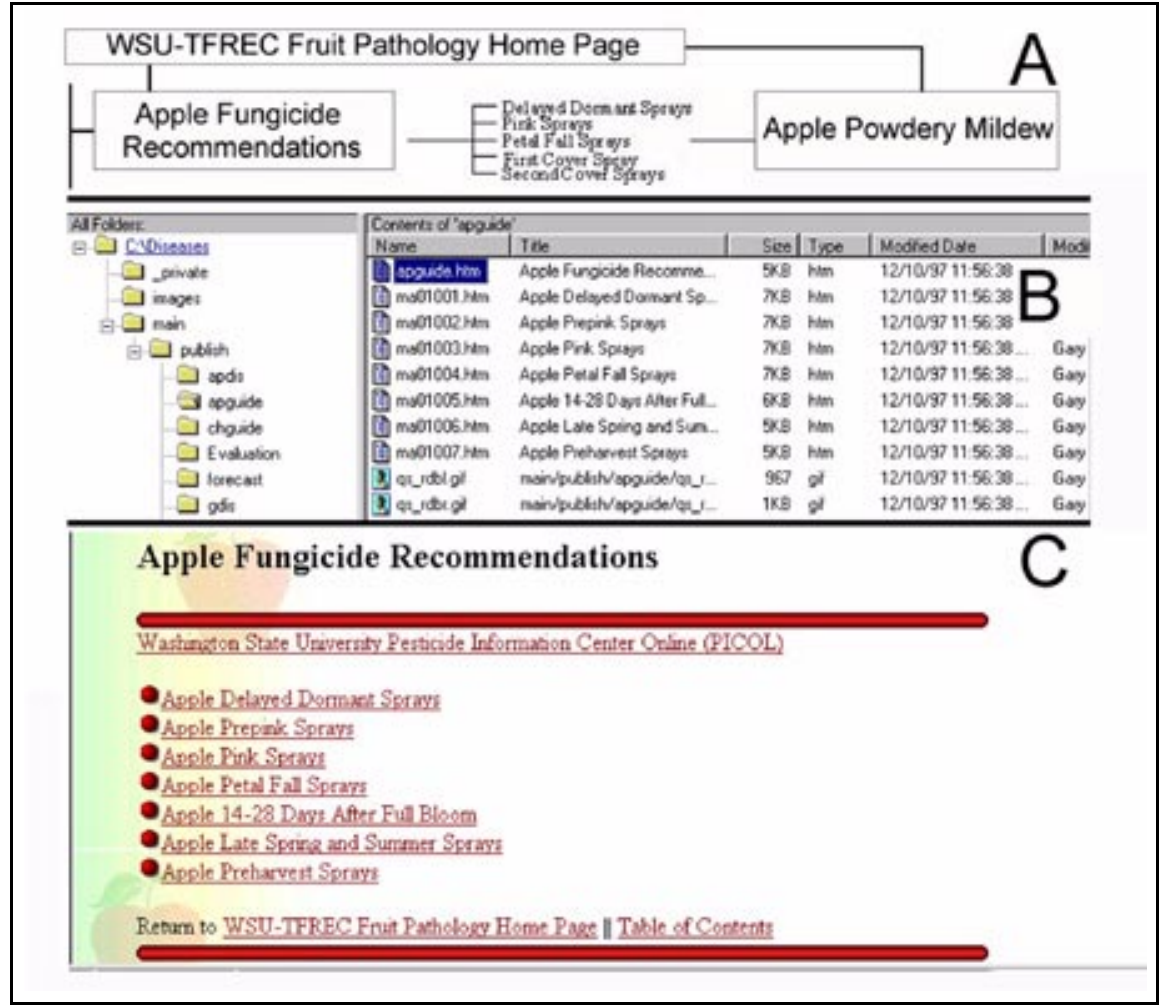

Fig 12. Diagrammatic ( $A$ ) and constitutive ( $B$ and $C$ ) representations of site structure of the WSU-TFREC Fruit Pathology site. Directions of arrows in A indicate direction of hyperlinks from general to specific information. Segment B illustrates HTML file structure within the apple disease (B) and apple fungicide recommendation areas (C) of the site. Blue and yellow icons represent menu and information-containing HTML pages, respectively.

definitions of terms, and advice for creation and maintenance of web pages and sites (Table 3).

There are several design and software factors to consider when creating a web site. One of the most critical decisions is the purpose and size of the site. These is envisioned, designing a flow chart at the onset of the project can save time and energy once site authoring and maintenance begins. Many web sites consist of only 1 or 2 pages and can be written and maintained with a number of free or inexpensive HTML authoring software packages (Table 3). The WVU and WSUTFREC Fruit Pathology sites consist of 193 and 92 HTML pages, respectively. Because of their complexity, large sites are best maintained with software designed for authoring and maintenance, such as Microsoft FrontPage, DeltaPoint Quick Site, or Adobe Site Mill for the Macintosh. A primary objective of both authors was to provide a uniform look and feel to pages within the site (WVU) or program discipline (WSU-TFRECFruit Pathology). Our experiences have shown that it is important to establish an easily navigable site, where visitors always know where to find information and how to find it rapidly. Easy navigation can be accomplished by constructing a comprehensive table of contents and menu bars (WSU-TFREC) or by incorporating innovative menus, hyperlinks, and "Active Channel" technology (WVU). One major advantage of site authoring software is that a "global change" (a change made on all pages comprising the site) can be made easily. The incorporation of even minor changes to large sites can be time-consuming if the changes must be made on each page. Site authoring tools also maintain a comprehensive list of file names, file status, and links (Fig. 12).

will determine what types of ware should be used for site construction Visualizing the size, structure, and internal and external linkages of a web site are, in the authors' opinion, the most important steps in establishing and maintaining a quality web site. If a large number of pages

\section{Getting Noticed on the Web}

Once you've created a web site and found a place to host it, your site will be one of approximately 4 million on the 


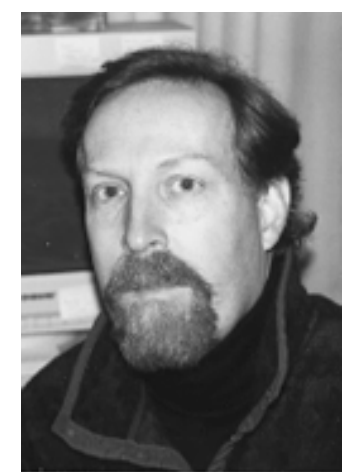

A. R. Biggs

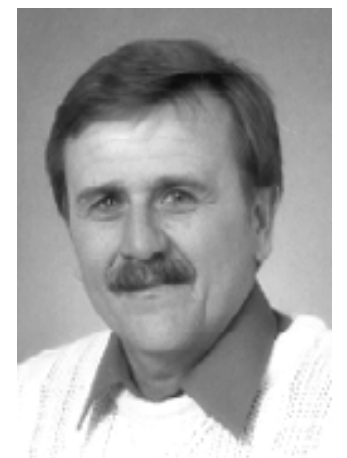

G. G. Grove

Dr. Biggs is professor of plant pathology and extension specialist for tree fruit diseases at West Virginia University's Kearneysville tree fruit research and education center. He received his Ph.D. in plant pathology from Pennsylvania State University in 1982. In 1983, Dr. Biggs was appointed research scientist with Agriculture Canada at the Vineland, Ontario, Research Station, a position he held until 1989. While there, he worked extensively with woody plant defense mechanisms and peach canker disease caused by Leucostoma spp. and brown rot of stone fruits. He has published more than 60 scientific articles in refereed journals and has prepared numerous book chapters, compendium articles, and extension publications. In addition, he edited two books, Defense Mechanisms in Woody Plants Against Fungi (Springer-Verlag, 1992) and Cytology, Histology, and Histochemistry of Fruit Tree Diseases (CRC Press, 1993). He serves currently on the electronic technology committee of the OEC. His research interests include alternative disease control strategies for fruit production, potential uses of calcium for disease suppression, woody plant defense mechanisms, and electronic communications in extension plant pathology. Dr. Biggs received the Lee M. Hutchins Award from APS for excellence in fruit research in 1993.

Dr. Grove is an extension plant pathologist at the Washington State University Tree Fruit Research and Extension Center in Wenatchee. He received his B.S. and M.S. degrees in botany from Ohio University and his Ph.D. in plant pathology from Ohio State University in 1984. Dr. Grove held a postdoctoral position at the University of California, Davis, before coming to WSU in 1986. His research focuses on the effects of meteorological and horticultural factors on the powdery mildews of tree fruits and grapes. He is the author of more than 40 refereed journal articles and more than 100 extension and popular press publications. Dr. Grove is interested in site-specific disease forecasting and has been a major factor in the movement of the Washington tree fruit industry toward electronic information transfer. He is a member of the APS Office of Electronic Communication, served as an associate editor of Phytopathology from 1992 to 1995, and is currently an associate editor of Plant Disease. He also teaches a course on fruit pathology at Wenatchee Valley College.

World Wide Web. Although advertising is anathema to most scientists, some skills in this area are required if your web site is to achieve its intended purpose. Some basic steps are routine for helping other computer users become aware of your site. First, if your site is designed for growers and agents, let these people know it is available by volunteering to speak at meetings, sending e-mail, and communicating with your state IPM coordinator. Second, register your site with several "search engines." This process involves the use of "meta-tags," which contain keywords that are embedded in your html pages and can be used to search for your site. Third, seek out sites that are similar or related to yours and propose to the site author that your two sites link to each other. Fourth, send out short, well-written e-mail press releases to bulletin boards or listservs (apple-crop@orchard.uvm.edu at http://orchard.uvm.edu/applecrop.html, for example). Be careful not to send these out to inappropriate places (this is called "spamming" and is bad etiquette). Fifth, put your site's URL in your e-mail signature file (the personalized message, or signature, that can be placed at the end of every one of your e-mail messages). Finally, promote your site offline. Have it listed on your business card and any popular publications or newsletters from your business or department.

An advertisement appears in the printed journal in this space. 


\section{Literature Cited}

1. Grove, G. G. 1991. Powdery mildew of sweet cherry: Influence of temperature and wetness duration on release and germination of ascospores of Podosphaera clandestina. Phytopathology 81:1271-1275.

2. Grove, G. G. 1996. Offramps on the information superhighway. Proc. Wa. St. Hortic. Assoc. 90:213

3. Grove, G. G., Boal, R. J., and Roberts, N. B. 1994. Influence of temperature and wetness duration on infection of cherry (Prunus avium L.) foliage by the shothole pathogen, Wilsonomyces carpophilus. (Abstr.) Phytopathology 84:1071.

4. Hogmire, H. W., Jr., ed. 1995. Mid-Atlantic Orchard Monitoring Guide. NRAES, Ithaca, NY.
5. Jones, A. L., and Sutton, T. B. 1997. Diseases of Tree Fruits in the East, NCR-45. Michigan State University, East Lansing.

6. Ley, T. W., and Muzzy, A. S. 1992. Experiences with and RF telemetry based automated weather station network in Washington state. Am. Soc. Agric. Eng. Pap. 922144, St. Joseph, MI.

7. Mills, W. D. 1944. Efficient use of sulfur dusts and sprays during rain to control apple scab. Cornell Ext. Bull. 630.

8. Schwarz, M. R., and Burr, T. J. 1984. Diagnostic Keys for Identification of Diseases on Apple, Peach, and Cherry Trees in the Northeastern United States. N.Y. Food Life Sci. Bull. 108.

9. Smith, T. J. 1993. A predictive model for forecasting fire blight of pear and apple in
Washington State. Acta Hortic. 338:153-157.

10. Smith, T. J. 1996. A risk assessment model for fire blight of apple and pear. Acta Hortic. 411:97-100.

11. Steiner, P. W. 1991. Fire blight prediction and control. In: New Directions in Tree Fruit Pest Management. K. Williams, ed. Good Fruit Grower, Yakima, Wa.

12. Thomas, C. S., Gubler, W. D., and Leavitt, G. 1994. Field testing of a powdery mildew disease forecast model on grapes in California. (Abstr.) Phytopathology 84:1070.

13. Warner, G. H. 1994. Computer bulletin board's significance growing. Good Fruit Grower 44(9): 16

14. Warner, G. H. 1995. Computers in the field. Good Fruit Grower 45(8):6-7. 